\title{
About transition processes in blasthole drilling at quarries
}

\author{
Andrey Regotunov*, Rudolf Sukhov, and Gennady Bersenyov \\ Institute of mining of the Ural branch of the Russian Academy of Sciences, 620075, 58, Mamina- \\ Sibiryaka st., Ekaterinburg, Russia
}

\begin{abstract}
As a system, the mining enterprise develops under constantly changing conditions of the external and internal environment. These conditions affect the state of the most important drilling subsystem: blasthole drilling technology, safety, performance, power consumption of the boring rigs and roller bits used. The main transition processes as necessary responses of the subsystem to changing conditions were identified as a result of fragmentary data analysis showing decisions taken over the past 15-20 years, which increase drilling activity efficiency and safety of smaller quarries of Russia, which contain a significant amount of material resources. The main transition processes contribute to the growth of drilling performance and consist of changing the following: bit design for specific rocks; drilling method; drilling mode; boring rig design; controlled parameters of drilling process and rock properties redetermination; parameters of maintenance and repair system. Based on the performed analysis, the systematization results of the main factors predetermining the need for transition processes implementation in the "drilling operations" subsystem were obtained and presented. The proposed approach allowed to reveal a holistic picture of the main interacting factors in the "drilling operations" subsystem. Based on the factors systematization presented in the article it is possible to envisage changes of individual factors depending on changes of other factors, not functionally related directly when planning drilling operations.
\end{abstract}

\section{Introduction}

At the present stage of operation, mining companies are large holdings and corporations that consume significant resources in the development of mineral deposits. Their operating conditions affect both general mining technology and drilling technology. Considering that drilling operations are associated with significant costs for the acquisition and operation of equipment used, boring tools, then untimely accounting of new drilling conditions for production wells in the development strategy of complex structure deep deposit planning can cause significant damage to the mining enterprise in the nearest and more distant perspective. Thus, changes in external and internal environmental factors necessitate early implementation of technological transition processes and drilling operations arrangement,

\footnotetext{
${ }^{*}$ Corresponding author: pochta8400@inbox.ru
} 
which are the actions made in the innovative decisions' implementation on drilling operations parameters adaptation to the changing conditions of the mining enterprise functioning [1,2]. Widespread variety of drilling equipment, availability of scientifically sound solutions to improve the drilling tools reliability $[3,4]$ and innovations in the field of blasthole drilling information technologies [5-9], research [10-15] in the field of boring rigs fleet completing optimization at quarries to minimize drilling costs - all of it creates a reliable basis for transitioning processes selection to adapt drilling parameters to changing conditions. In such a situation, mining companies are forced to conduct a thorough review of their activities to identify genuinely essential solutions. The greatest difficulty in assessing possible reserves to increase efficiency and reduce risks of hazardous situations for the company is the low awareness level of the different factors impact under specific conditions. Factors significance assessment is often made based on the experience and intuition of individual specialists of mining enterprises. This approach does not consider the systemic factors impact and critical inter-factorial linkages, resulting in either over expenditure or lack of resources and increased risks of production losses.

\section{Identification of major transition processes implemented in drilling operations on major quarries of Russia}

Based on the data obtained by Institute of mining of the Ural branch of the Russian Academy of Sciences [16-18] and specified in the literature [19-29], the main transition processes carried out in carrying out drilling operations on mining enterprises of Russia were determined. The studies considered measures or actions implemented over the past 10 to 15 years in mining enterprises that achieved planned capacity and faced the need for transition processes implementation in drilling operations. The totality of the diverse identified data on drilling operations transition processes in various mining enterprises has been classified into several main groups (table 1). Table 1 also shows the transition processes implementation results and their impact on related mining processes (explosive rupture, excavation, transportation, primary breaking in a crushing-andconcentrating plant).

As a result of the study, it was determined that the efficiency and safety of drilling operations is mainly determined by transition processes related to obtaining information on the state of the rocks in natural deposit, change in the method and mode of drilling, design of boring rigs and tools, parameters improvement of maintenance and repairs system. As shown by the analysis, these areas have significant reserves for the development of drilling operations and deserve special attention in stabilizing the changing conditions influence of open mining operations. The studies also showed that in order to improve the drilling operations efficiency in mining enterprises, transition processes that disclose internal reserves of boring rigs and tools without significant production capital investment should be used. It was also found that the productivity growth potential of drilling machinery is mainly considered in the assessment of the possible effect from the transition processes implementation in drilling operations. Thus, having information on the need to optimize certain factors affecting the efficiency and/or safety of quarry drilling operations, it is possible to identify a potential list of adaptive transition processes based on table 1 . Subsequently, the selected transition processes should be brought to full compliance with the conditions of a particular mining enterprise. 
Table 1. Transition processes in drilling operations at mining enterprises of Russia

\begin{tabular}{|c|c|c|c|c|c|}
\hline \multirow{2}{*}{ 言 } & \multirow{2}{*}{ 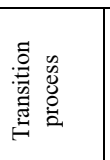 } & \multirow[t]{2}{*}{ Mining enterprise } & \multirow{2}{*}{$\begin{array}{c}\text { Implementation results in } \\
\text { enterprises }\end{array}$} & \multicolumn{2}{|c|}{ Objective factors } \\
\hline & & & & & Organizational and technical \\
\hline 1 & 2 & 3 & 4 & Systemic & 6 \\
\hline \multirow[t]{19}{*}{ I } & \multirow{19}{*}{ 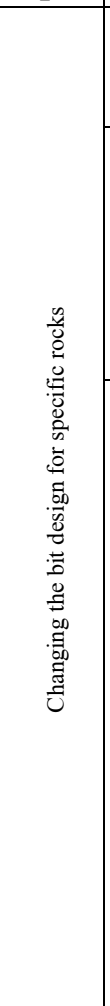 } & \multirow{3}{*}{$\begin{array}{c}\text { Uralasbest JSC } \\
\text { Kachkanarsky GOK, } \\
\text { Kostomukshsky GOK } \\
\text { [16], Polyus PJSC }\end{array}$} & \multirow{3}{*}{$\begin{array}{l}\text { Increasing bits endurance, } \\
\text { reducing drilling tool costs by } \\
35-40 \% \text {. }\end{array}$} & \multirow{6}{*}{ 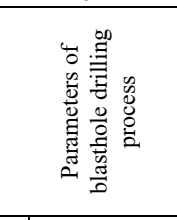 } & Blasthole diameter \\
\hline & & & & & Design parameters of roller bit \\
\hline & & & & & Drilling tools durability \\
\hline & & \multirow{5}{*}{$\begin{array}{c}\text { Kachkanarsky GOK } \\
{[17,18]}\end{array}$} & \multirow{5}{*}{$\begin{array}{l}\text { Increasing boring rig } \\
\text { productivity by } 2-2.5 \text { times in } \\
\text { comparison with rotary BR - } \\
250 \mathrm{MN} \text {. High quality rock } \\
\text { crushing is provided. }\end{array}$} & & Mechanical drilling speed \\
\hline & & & & & Drilling rig performance \\
\hline & & & & & Drilling unit costs \\
\hline & & & & \multirow{4}{*}{ 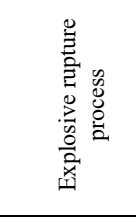 } & $\begin{array}{l}\text { Particle size distribution of } \\
\text { ruptured rock }\end{array}$ \\
\hline & & & & & $\begin{array}{l}\text { Shape and width of exploded } \\
\text { rock }\end{array}$ \\
\hline & & \multirow{11}{*}{$\begin{array}{c}\text { In the conditions of } \\
\text { Kostomukshsky GOK } \\
{[19]} \\
\text { In the conditions of } \\
\text { quarry of Krasnoyarsk } \\
\text { Krai and Khakassia - } \\
\text { Gorevsky GOK, } \\
\text { Polyus PJSC [20] }\end{array}$} & \multirow{11}{*}{$\begin{array}{l}\text { The application of foreign } \\
\text { roller bits provided durability } \\
\text { increase by } 2 \text { times compared } \\
\text { to bits of domestic production. } \\
\text { The cost of foreign roller bits } \\
\text { exceeded the cost of domestic } \\
\text { bits by } 2 \text { times and more. }\end{array}$} & & Explosive application rate \\
\hline & & & & & Mined rock output \\
\hline & & & & $\infty . \overline{0}$ & Excavator bucket capacity \\
\hline & & & & రె & Loading cycle duration \\
\hline & & & & 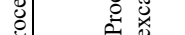 & Excavator productivity \\
\hline & & & & -4 & Excavation energy intensity \\
\hline & & & & 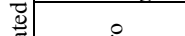 & Vehicle body space \\
\hline & & & & ప્a & $\begin{array}{c}\text { Vehicle } \\
\text { cargo carrying capacity }\end{array}$ \\
\hline & & & & 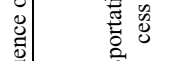 & $\begin{array}{c}\text { Energy intensity of } \\
\text { transportation }\end{array}$ \\
\hline & & & & 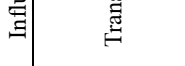 & Vehicle productivity \\
\hline & & & & 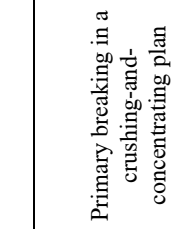 & $\begin{array}{c}\text { Crusher parameters (grip angle, } \\
\text { throughput, motor power) }\end{array}$ \\
\hline \multirow[t]{7}{*}{ II } & \multirow{7}{*}{ 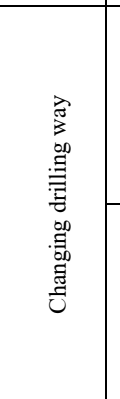 } & \multirow[b]{2}{*}{$\begin{array}{l}\text { at most of Russia's } \\
\text { quarries }\end{array}$} & \multirow{2}{*}{$\begin{array}{l}\text { As a result of the transition from } \\
\text { the cable-churn drilling method } \\
\text { to the roller-bit drilling, drilling } \\
\text { productivity has been } \\
\text { significantly improved and } \\
\text { economic costs have been } \\
\text { significantly reduced. }\end{array}$} & \multirow{7}{*}{$\begin{array}{c}\text { Parameters of } \\
\text { blasthole drilling } \\
\text { process }\end{array}$} & Rupture mechanism parameters \\
\hline & & & & & Auxiliary operations time \\
\hline & & \multirow{5}{*}{$\begin{array}{l}\text { Mikhailovsky GOK. } \\
\text { Selectively on } \\
\text { selected sites }\end{array}$} & & & Operations' laboriousness \\
\hline & & & drilling mode provided improved & & Mechanical drilling speed \\
\hline & & & drilling productivity. Thermal & & Rig time usage ratio \\
\hline & & & application scope due to $\mathrm{SiO}$ & & Drilling tool structure \\
\hline & & & $\begin{array}{c}\text { content in the rock massif (must } \\
\text { be at least } 68-72 \% \text { ). }\end{array}$ & & Drilling process safety \\
\hline III & & Coal strip mines of & Reduced engine room floor & & Mechanical drilling speed \\
\hline & & SUEK [21-23], & vibration and machinist & & Drilling rig performance \\
\hline & 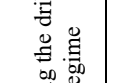 & $\begin{array}{l}\text { quarries of Alrosa } \\
\text { PJSC, Polyus PJSC, } \\
\text { Mazulsky limestone }\end{array}$ & $\begin{array}{l}\text { workplace vibration, increased } \\
\text { replacement performance by } 15 \\
\text { percent or more. }\end{array}$ & $\begin{array}{l}\text { Parameters of } \\
\text { blasthole drilling }\end{array}$ & Bit durability \\
\hline & 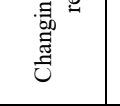 & $\begin{array}{l}\text { mine of Rusal- } \\
\text { Achinsk JSC, } \\
\text { Nefelinovy mine of } \\
\text { Rusal JSC, }\end{array}$ & $\begin{array}{l}\text { Increase in drilling speed by } \\
30-40 \% \text { without roller bits } \\
\text { durability reduction. }\end{array}$ & & $\begin{array}{l}\text { Oscillation dynamics of drill } \\
\text { string and roller bit }\end{array}$ \\
\hline IV & & On the quarries of & As a result of the factory & & Mechanical drilling speed \\
\hline & 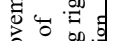 & Russia: & modernization of SBSH- & & Shift time \\
\hline & 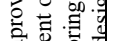 & Kachkanarsky GOK, & 250MNA-32 drilling rigs & blasthole drilling & Working time utilization factor \\
\hline & 国 $\bar{\delta}$ & Lebedinsky GOK, & carried out by Rudgormash & & Auxiliary operations time \\
\hline & & Mikhailovsky GOK, & JSC over the past 15 years, & & Hole diameter \\
\hline
\end{tabular}




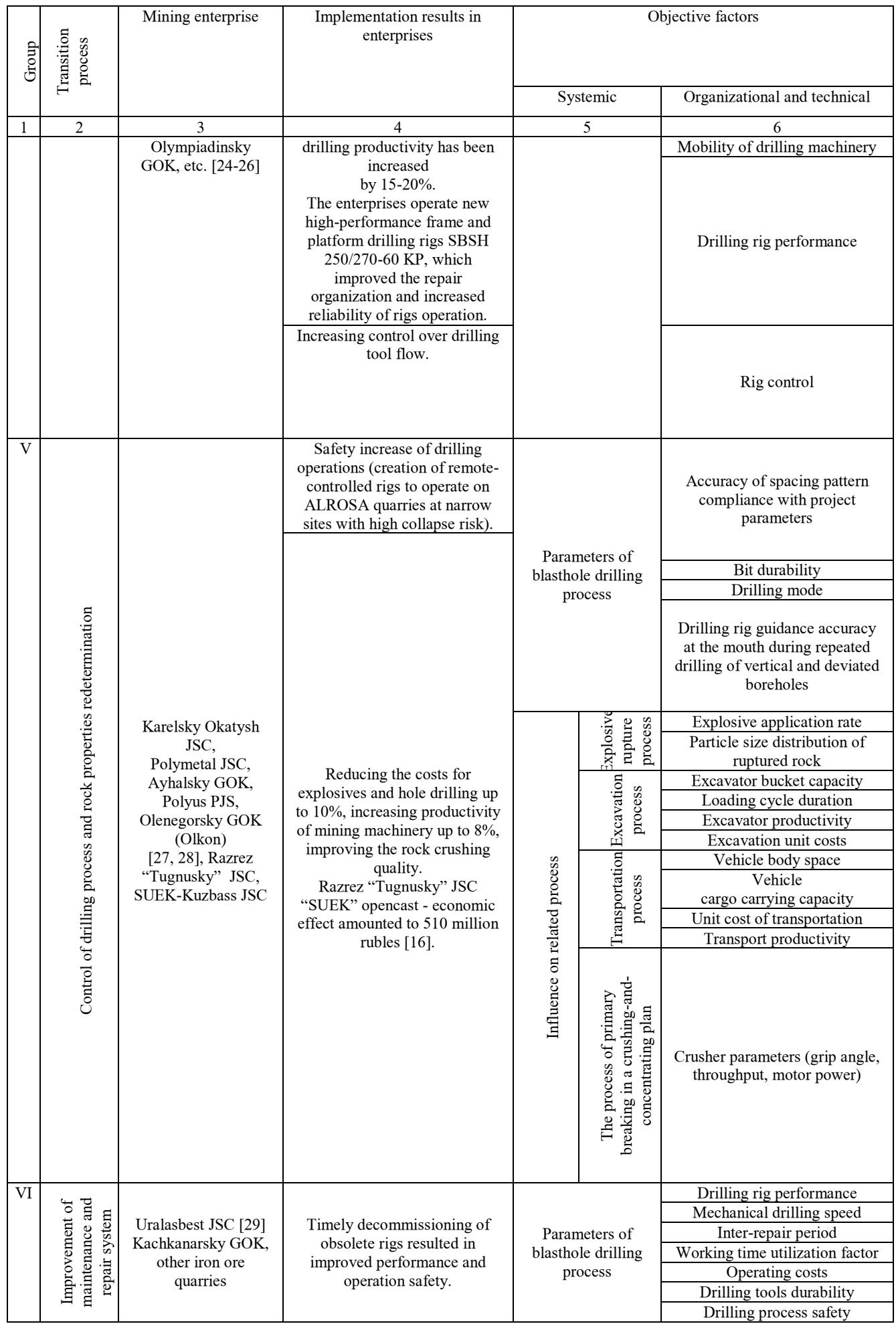




\section{Systematization of factors that determine the need for transition processes implementation in drilling operations}

Application of the methodological approach proposed by the corresponding member of the Russian Academy of Sciences, Doctor of Technical Sciences V.L. Yakovlev [30] on the basis of previously established results revealing transitions in drilling operations, allows to perform the decomposition of the "drilling operations" subsystem on elements and systematize the factors (Figure 1) that predetermine the onset of transition processes during drilling operations. At the same time, it is important to understand their mutual influence for managing the transition processes implementation.

The factors systematization presented in Figure 1 has revealed stable recurring relationships between them; when considering, it is possible to understand the overall functioning of the "drilling operations" subsystem and determine which of the factors are independent, objective and manageable. Independent factors include external factors, the impact of which is almost impossible to rule out, such as changes in electricity tariffs, lower demand for minerals due to market oversaturation, and others.

Changes in environmental factors are restrictive. For example, changes in the minerals price, demand, inflation - all of them indirectly determine the requirements for specific consumption, the type of material and energy resources used in drilling operations, technical perfection level of the technique used, stages and duration of transition to new models of drilling rigs.

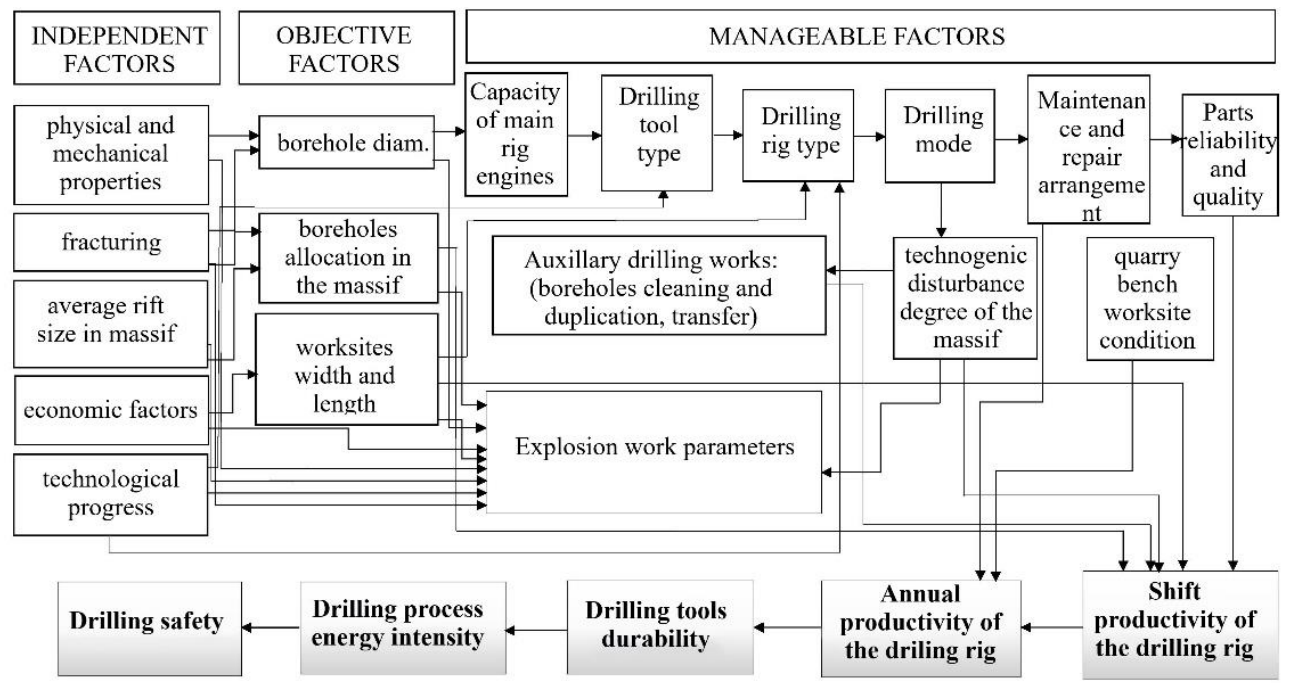

Fig. 1 Systematization of the main factors that predetermine the need for implementation of transition processes in the subsystem "drilling operations".

Objective factors significantly influence the structure and parameters of the "drilling operations" subsystem and are determined by external factors, that is independent of the activity of the enterprise. Manageable factors are interrelated with objective factors and influence the timely selection of transition processes, implementation of which becomes manageable considering previously identified inter-factorial links. This allows the necessary and enough resources to be sought in advance to improve the efficiency and safety of blasthole drilling at the quarry under changing mining conditions of minerals. The control factors include, for example, the reliability and quality of the parts applied that 
affect the breakage rate of the drilling rig, the durability of the drilling tool and accordingly the safety and efficiency (productivity) of the drilling rig.

Factors systematization results accounting done by specialists of mining companies will allow for rational transition processes to stabilize or increase a certain indicator of the "drilling operations" subsystem state, for example, the shift performance of the drilling rig, take into account not only the physical and mechanical properties of rocks, but also pay attention to the quality of quarry bench worksites preparation and the impact of the technogenic disturbance degree of the rock massif, depending on the parameters of blasting (Figure 1). Based on the established systematization it is possible to envisage changes of individual factors depending on changes of others not connected by an explicit functional link at the stage of planning. For instance, the annual productivity values of the drilling rig may experience variations of a certain periodicity depending on the quality and frequency of repairs and maintenance carried out. The roller bits endurance index may change due to the erroneous prediction of the drillability grade (physical and mechanical properties) within the section (sections) and/or drilling tools inconsistency to the manufacturer's declared characteristics and/or non-compliance with operating regulations.

\section{Conclusion}

As a result of the studies, transition processes have been identified, preventing the negative impact of the changing conditions of developing complex mineral deposits and increasing efficiency and safety of innovations adoption in drilling technology. The main factors that predetermine the changes in conditions and the need for the transition processes implementation of drilling operations in quarries were determined and systematized. In practical terms, the research results can be applied to the auditing of drilling operations at mining enterprises with an open mode of mining and identification of rational controlled transition processes that adapt the parameters of drilling technology to changing conditions of internal and external environment.

\section{Acknowledgements}

The authors of the publication express gratitude and deep thankfulness to the corresponding member of the Russian Academy of Sciences, Doctor of Technical Sciences, Professor V.L. Yakovlev, Doctor of Technical Sciences, Professor S.V. Kornilkov for valuable advice and recommendations in the supervising process of the research work on the topic of the article, employees of the laboratory of rock fragmentation of the Ural Branch of the Russian Academy of Sciences: Candidate of Technical Sciences S.N. Zharikov, Candidate of Technical Sciences A.A. Kotyashev, V.A. Kutuev, P.V. Menshikov, A.S. Flyagin, S.S. Taranzhin for assistance in conducting research and preparation of this article.

The research was carried out within the framework of the State order №075-00581-19-00, topics №0405-2019-0005 (2019 - 2021).

\section{References}

1. V. L. Yakovlev, Mining Information and Analytical Bulletin (Scientific and Technical Journal), S1-1, 65 (2015)

2. V. L Yakovlev, A. V. Glebov, A. G. Zhuravlev, Rational development of subsoil, 1 (2019) 
3. D. I. Simisinov, A. I. Afanasiev, V. S. Shestakov, N. G. Valiev, Gornyi Zhurnal, 9, 97 (2019) doi 10.17580/gzh.2019.09.14

4. A. I. Afanasiev, D. I. Simisinov, V.S. Shestakov, Gornyi Zhurnal, 9, 52 (2014)

5. A.S. Regotunov, R.I. Sukhov, E3S Web of Conferences conference proceedings, 01002 (2018) doi 10.1051/e3sconf/20185601002

6. S. N. Zharikov, Bulletin of Universities. Mining Journal, 1, 21 (2019)

7. P. Hatherly, S. J. Scheding, R. Leung, D. Robinson, International Journal of Rock mechanics and Mining Sciences, 78, 144 (2015)

8. V.C. Kelessidis, The Journal of The Southern African Institute of Mining and Metallurgy, 111, 429 (2011)

9. V. Krúpa, M. Kruláková, E. Lazarová, M. Labaš, K. Feriančiková, L. Ivaničová, Measurement, 117, 165 (2018)

10. A. S. Regotunov, V. A. Antonov, Proceedings of TulSU. Earth Sciences, 1, 191 (2019)

11. N. Bilim, A. Çelik, B. Kekeç, Journal of African Earth Sciences, 134, 564 (2017)

12. M. A. Sayed, Bulletin of the faculty of Engineering, Assiut University, 29, 3 (2/2), 255 (2001)

13. S. T. Hassan, MSc thesis, Faculty of Engineering, Assiut University, (2006)

14. T. B. Afeni, Mining Science and Technology (China), 19 (6), 736, (2009) doi 10.1016/S1674-5264(09)60134-4

15. Yu. I. Lel, A.V. Zakharov, Mining Information and Analytical Bulletin (Scientific and Technical Journal), 199 (2011)

16. R. I. Sukhov, D. C. Shakhmatov, I. V. Pankov, Mining Journal, 3, 26 (1991)

17. R. I. Sukhov, International Conference on Open Mining, 196 (1996)

18. R. I. Sukhov, Mining Journal, 8, 25 (1995)

19. Yu. Yu. Lubenets, Mining Journal, 5, 42 (2004)

20. K. A. Bovin, A.V. Gilev, A. O. Shigin, I. S. Plotnikov, Proceed. of Sib.dep. of RANS. Geology, search and exploration of ore deposits, 40, 99 (2017)

21. E. A. Zagrivny, Dynamic Models and Sustainability of the subsystem "executive body - face" of the mining machine: author's thesis of the Doctor of Engineering Sciences, 39 (1996)

22. B. N. Kutuzov, Blasting,392 (1980)

23. A. O. Shigin, Bulletin of IrSTU, 10 (93), 59 (2014)

24. A.V. Tokarenko, E.V. Gulenkov, Mining Journal, 3, 76 (2013)

25. V.V. Zenin, Coal, 10 (978), 50 (2007)

26. V.D. Butkin, A.V. Gilev, R.A. Gilev, D.S. Dogadin, D.B. Nekhoroshev, V.T. Chesnokov, Selection and rational operation of drilling tools and rigs at quarries, 236 (2010)

27. V.A. Kovalenko, Mining industry, 3 (07), 50 (2017)

28. A.O. Shigin A.A. Shigina, Mining Journal, 2, 79 (2017)

29. O. Yu. Konteev, A. G. Khudyakov, Yu. V. Bolkiseva, V. S. Bolkisev, Mining Information and Analytical Bulletin (Scientific and Technical Journal), 10, 165 (2009)

30. V. L. Yakovlev, Mining Information and Analytical Bulletin (Scientific and Technical Journal), S24, 138 (2017) 